Original Research Paper

\title{
Prediction and Remediation of Water Quality in Monitoring Potential of Acid Mine Drainage
}

\author{
Nur Athirah Mohamad Basir, Wan Zuhairi Wan Yaacob, \\ Nuur Hani Mohammed, Mustapha Atta and Nur Aishah Zarime \\ Geology Programme, School of Environmental Sciences and Natural Resources, \\ Faculty of Science and Technology, Universiti Kebangsaan Malaysia, 43600 Bangi, Selangor, Malaysia
}

Article history

Received: 21-12-2017

Revised: 08-03-2018

Accepted: 18-04-2019

Correspondings Author: Nur Athirah Mohamad Basir Geology Programme, School of Environmental Sciences and Natural Resources, Faculty of Science and Technology, Universiti Kebangsaan Malaysia, 43600 Bangi, Selangor, Malaysia

Email: eroh89@yahoo.com.my

\begin{abstract}
Acid Mine Drainage (AMD) associated with both active and abandoned mining operations related to sulfide minerals, oxidation of pyrite affording an acidic solution that contains toxic metal ions. Result shows that $\mathrm{pH}$ value of water in $\mathrm{Kg}$. Aur, Chini and $\mathrm{Sg}$. Lembing are acidic with value of $2.81,4.16$ and 3.60 respectively. Maximum concentrations of heavy metals in the study area are: $\mathrm{Pb}(0.2 \mathrm{mg} / \mathrm{L}), \mathrm{Cd}(0.05 \mathrm{mg} / \mathrm{L}), \mathrm{Zn}(5.1$ $\mathrm{mg} / \mathrm{L}), \mathrm{Cu}(5.2 \mathrm{mg} / \mathrm{L}), \mathrm{Mn}(10.9 \mathrm{mg} / \mathrm{L}), \mathrm{Cr}(0.2 \mathrm{mg} / \mathrm{L}), \mathrm{Ni}(0.2 \mathrm{mg} / \mathrm{L}), \mathrm{As}$ $(0.005 \mathrm{mg} / \mathrm{L})$ and $\mathrm{Fe}(202.69 \mathrm{mg} / \mathrm{L})$. Prediction of acid formation using acid-base calculations from all samples shows high potential acid production between 22.84-2500.16 $\mathrm{kg} \mathrm{CaCO}_{3} /$ tonne. The ratio of Neutralization (NP) with Acid Potential (APP) shows a very low value $($ ratio $<1)$ Sg. Lembing (0.02), Chini (0.08), Selinsing (0.31) and Kg. Aur (0.81). Analysis from the tank experiment after 30 days shows $\mathrm{pH}$ of LFS, bentonite, activated carbon and zeolite change to 6.11, 3.91, 2.98 and 2.71 respectively. Three mine sites experiencing AMD are Kg. Aur, Chini and Sg. Lembing. Active neutralization treatment successfully shows LFS has great potential to control AMD based on their ability to neutralize the $\mathrm{pH}$ and remove heavy metals in the mine water. Meanwhile, the second adsorbent material is bentonite followed by activated carbon and zeolite.
\end{abstract}

Keywords: AMD, Heavy Metals, Acid-Base Accounting (ABA), Remediation

\section{Introduction}

Acid Mine Drainage is quite new environmental problem in Malaysia (Madzin et al., 2016). Mineral processing of hard rock, metal ores (e.g., $\mathrm{Au}, \mathrm{Cu}, \mathrm{Pb}$, $\mathrm{Zn}$ ) and industrial mineral deposits (e.g., phosphate, bauxite) involves the size reduction and separation of the individual minerals. Consequently, the end products of ore or industrial mineral processing are concentrated of the sought-after commodity and a quantity of residue wastes known as tailings (Young et al., 2017). Rock waste or tailings from the weathering of pyrite $\left(\mathrm{FeS}_{2}\right)$ and sulfide minerals can contribute to Acid Mine Drainage AMD (Johnson and Hallberg, 2005). The potential presence of acidic environment when these rocks contain metal sulfides, especially iron disulfide (FeS2) which is pyrite and or marcasite, they become oxidized by air and water producing $\mathrm{Fe}^{2+}, \mathrm{H}^{+}$and $\mathrm{SO}_{4}{ }^{2-}$ ions. When these ions get into the solution, sulfuric acid is produced (AMD). Prediction the potential of AMD can be exceedingly challenging and costly due to mineralogy and other factors that are highly variable from site to site (USEPA, 1994). Static and kinetic geochemical tests are commonly used to predict AMD generation. Static tests involve determination of Net-Acid Production Potential (NAPP) and/or Net Acid Generation (NAG) values (expressed in either $\mathrm{kg} \mathrm{H}_{2} \mathrm{SO}_{4} / \mathrm{t}$ as used here or $\mathrm{kg} \mathrm{CaCO}_{3} / \mathrm{t}$ ). NAPP is calculated through Acid Base Accounting (ABA) procedures. Positive NAPP values indicate a potential to generate acid. NAG values are obtained through the reaction of pulverised sample with $\mathrm{H}_{2} \mathrm{O}_{2}$ to accelerate sulphide oxidation with the resulting liquor titrated with $\mathrm{NaOH}$ and $\mathrm{NAG}\left(\mathrm{kg} \mathrm{H}_{2} \mathrm{SO}_{4} / \mathrm{t}\right)$ values calculated. Its environmental impact, however, can be minimized at three basic levels: Through primary prevention of the acidgenerating process; secondary control, which involves the deployment of acid drainage migration prevention measures; and tertiary control, or the collection and treatment of effluent (Akcil and Koldas, 2006).

The choice of which option to use to remediate AMD is dictated by a number of economical and environmental factors (Barrie and Kevin, 2005). Active 
treatment involves regular reagent and labour inputs, while passive treatment only requires occasional maintenance (Jeff et al., 2005). The addition of chemical-neutralizing agent, is an active treatment process to mitigate acidic effluents (Coulton et al., 2003). In general, an adsorbent is assumed as "lowcost" if it needs very little processing, is abundant in nature, or could be a byproduct or waste material from another business (Haider et al., 2014). The use of natural material from clay mineral has undoubtedly become more popular and widely used as an adsorbent especially for removing heavy metal, organic pollutants and nutrients (Abdelaal, 2004). Clay minerals, such as bentonite and zeolite, are some of the potential alternatives, as they have large specific surface areas with a net negative charge, which can be electrically compensated for by inorganic and organic cations from the environment (Konig et al., 2012). The industrial by products could be assumed to be the low-cost adsorbents due to their abundance in nature and less processing requirements. The slag as an alternative adsorbent has been used to remove heavy metals in the environmental field due to its unique properties (Dias et al., 2007; Barakat, 2011). The aimed of this study are to investigate the acid mine drainage potential through analytical tests which is static tests. The characteristic of different adsorbents material (LFS, zeolite, bentonite, kaolinite and active carbon) and the adsorption of heavy metals $(\mathrm{Cd}, \mathrm{Fe}$, $\mathrm{Mn}, \mathrm{Cu}, \mathrm{Zn}, \mathrm{Pb}$ and $\mathrm{Ni}$ ) have been investigated in controlling AMD occurrence, improving water quality and to identify immobility mechanism of metals through a series of tank experiments.

\section{Materials and Methods}

\section{Mining Site Sampling Procedure}

The studies were conducted at four active mining sites and five abandoned mining sites (Table 1). Samples such as water, rock, tailing and soil were collected. Water analysis of in-situ parameters such as $\mathrm{pH}$, dissolved oxygen, potential production, temperature, salinity and conductivity were measured by using Quality meter YSI 656. For water sampling, one liter of water was collected from each sites and preserved by adding ultra-pure acid and then the samples were stored in a cooler box of approximately $4^{\circ} \mathrm{C}$ before being transported to the laboratory for further analysis. The waste rock samples were collected and put in plastic bag for each site. Meanwhile, tailings and soils were collected from nine sites and for each sampling site, 2-3 $\mathrm{kg}$ of the samples were packed and sealed in prewashed plastic bags to maintain its characteristics.

\section{Analysis of Water from Mining Site}

The water analysis procedures are obtained from following steps. Firstly, the AMD solutions were filtered through a membrane of $0.45 \mu \mathrm{m}$ pore to get the clear effluent before tested. Heavy metal elements $(\mathrm{Cd}, \mathrm{Pb}$, $\mathrm{Zn}, \mathrm{Cu}, \mathrm{Mn}, \mathrm{Ni}, \mathrm{As}$ and $\mathrm{Cr}$ ) and major cation $(\mathrm{Ca}, \mathrm{Mg}$, $\mathrm{K}, \mathrm{Na}$ as well as $\mathrm{Fe}$ ) were determined by using Inductively Coupled Plasma Mass Spectrometry (ICPMS) model of Perkin Elmer Elan900. Meanwhile, for major anions (sulfate and chloride) analysis was conducted by filtered the solution through $0.2 \mu \mathrm{m}$ pore size. Metrohm 850 Professional Ion chromatography with chemical suppression was performed to measure sulfate and chloride anion contents

\section{Analysis of Rock and Soil}

Physical-chemical tests such as $\mathrm{pH}$, neutralization potential, total sulfur of rock and soil were determined using standard method of USEPA (Sobek et al., 1978). A representative $250 \mathrm{~g}$ portion was prepared by splitting, dried and pulverized to less than $0.25 \mathrm{~mm}$ for the titration test. The $\mathrm{pH}$ of the samples obtained by adding $10 \mathrm{~g}$ of soil and mixed with $25 \mathrm{ml}$ distilled water and then stirred with spatula continuously. The $\mathrm{pH}$ value was measured by using Hanna measurement $\mathrm{pH}$ instrument with the ratio of water and sample was 1:2.5. The $\mathrm{pH}$ meter calibrated with buffer solution at $\mathrm{pH}: 4$ and $\mathrm{pH}: 7$. Total sulfur in the sample represents the maximum potential of acidity followed by E1915-97 method (ASTM 2000a) (Smith et al., 1974).

Table 1: The parameter and characteristic of the mining sites

\begin{tabular}{|c|c|c|c|c|}
\hline Mining sites & GPS coordinate & Type of minerals & Status until 2013 & Types of site \\
\hline Bukit Ibam & N03'10'12.8"/E102'58'05.5" & Iron & Active & Pond \\
\hline Kg. Aur (Upper) & N 03'08'11.8"/102'57'38.9" & Hematite & Abandoned & Stream \\
\hline Kg. aur (Bottom) & N03'08'05.3"/E102'58'07.1" & Hematite & Abandoned & Stream \\
\hline Chini & N03'23'34.9"/E102'56'46.1" & Manganese & Abandoned & Pond \\
\hline Sungai Lembing & N03'54'35.2"/E103'01'51.1" & Tin & Abandoned & Stream \\
\hline Kuari JKR Kg. Awah & N03'29'51.8"/E102'32'30.4" & Andesite & Abandoned & Pond \\
\hline Kuari Kota Gelanggi & N03'53'09.1"/E102'28'42.6" & Limestone & Abandoned & Pond \\
\hline Kg. Besul & N04'00'09.4"/E102'18'37.3" & Iron & Active & Pond \\
\hline Selinsing & N04'14'54.2"/E101'47'14.5" & Gold & Active & Pond \\
\hline Batu Malim & N03'58'02.1"/E101'46'27.5" & Iron & Active & Pond \\
\hline
\end{tabular}




\section{Analysis of Tailings}

Toxicity Characteristic Leaching Procedure (TCLP) for these soils was determined using USEPA Method 1311 (1999). After sampling, holding time for metal have 180 days until leaching, except for mercury where leaching must start within 28 days. $10 \mathrm{~g}$ of soil was mixed with glacial acetic acid (adjusted to $\mathrm{pH} 4.93$ with $1 \mathrm{~N} \mathrm{NaOH}$ ) at $20 \mathrm{~L} \mathrm{~kg}^{1}$ in polypropylene bottle. Then the bottle was agitated with junior orbital shaker at $200 \mathrm{rpm}$ for $18 \mathrm{~h}$. After $18 \mathrm{~h}$, the liquid was filtered through 0.45 $\mu \mathrm{m}$ membranes, acidified with concentrated nitric acid and stored in amber vials at $4^{\circ} \mathrm{C}$. TCLP tests are completed in a short (18-h) contact duration. The metal concentrations such as $\mathrm{As}, \mathrm{Ba}, \mathrm{Cd}, \mathrm{Cr}(\mathrm{VI}), \mathrm{Pb}, \mathrm{Se}, \mathrm{Ag}$, $\mathrm{Hg}$ were determined by Inductively Coupled Plasma Mass Spectroscopy (ICP-MS).

\section{Prediction of $A M D$}

Static tests are geochemical analyses of sulfide waste which are used to predict the potential of a waste sample to produce acid. A significant part of the static test is Acid Base Accounting (ABA), which refers to the numerical data used to predict acid generation. The three components of the ABA are: (i) Determination of acid production; (ii) Determination of acid consumption; and (iii) Calculation of net acid production or consumption using the data from (i) and (ii). Here, (i) Determination of acid production from tailings samples deals with the measurement of total sulfur, which is the main goal of research. Acid Production Potential (APP) based on the assumption that two moles of acid will be produced for each mole of sulfur present in the mine waste. The total sulfur content in percent is multiplied by 31.25 to yield the APP in units of tons acidity as $\mathrm{CaCO}_{3}$ per 1000 tons rock (or equivalently, $\mathrm{kg} \mathrm{CaCO}_{3} /$ metric ton). Neutralization Potential (NP) test was performed to determine the quantity of acid-consuming minerals in a sample (Sobek et al., 1978). The NP test started with "a fizz test" which was done by adding one or two drops of $25 \% \mathrm{HCl}$ solution to about $0.5 \mathrm{~g}$ of sample and observing the degree of effervescence. The fizz test was used to rank sample as none, slightly, moderate and strong. The appropriate amount and concentration of $\mathrm{HCl}$ was added to $2.0 \mathrm{~g}$ of sample in a flask and placed on a hot plate until the sample was just beginning to boil. The flask was taken off the heat and swirled intermittently until no more effervescence was observed. More distilled water was added to make a total volume of $125 \mathrm{ml}$. After heated for $1 \mathrm{~min}$, the sample was left to cool down above room temperature before titration. The sample is then titrated with $1.0 \mathrm{~N}$ sulfuric acid until a $\mathrm{pH}$ of 7.0 is reached. The $\mathrm{pH} 7$ was selected since this $\mathrm{pH}$ represents the amount of acid that a mine waste could neutralize while maintaining drainage $\mathrm{pH}$ in a range that meets quality standards. Prediction of acid is determined by the Net Neutralization Potential (NNP), which is the difference between these values $(\mathrm{NNP}=\mathrm{NP}-\mathrm{APP})$.
Typically, this difference is initially assessed by AcidBase Accounting (ABA) to determine the Net Acid Production Potential (NAPP) of a sample. ABA test was developed by Smith et al. (1974) and subsequently modified by Sobek et al. (1978) to evaluate the acid producing capacity of coal mine wastes. Sobek et al. (1978) indicated that waste would produce acid if and only if NNP was less than $-5 \mathrm{~kg} \mathrm{CaCO} /$ ton.

\section{Treatment Materials Preparation}

The preparation of raw Ladle Furnace Slag (LFS) material start by air-dried at room temperature for one week. The dried and raw-shaped of LFS then was ground using a mechanical grinding and mortared manually to form fine-pollen of material before experimental work start. Meanwhile the natural materials used in this research originated from different places, for example kaolinite sample was obtained from Perak, bentonite sample from Australia, zeolite sample from Indonesia and active carbon originated from Seremban, Negeri Sembilan respectively. These dried-sample were sieved using a manual sieved (standard test sieve ASTMII Specification) to obtain particle size of $0.063 \mathrm{~mm}$. The sample collected are usually characterized using several laboratorial techniques, such as Inductively Coupled Plasma-Atomic Emission Spectrometry (ICP-AES), X-Ray Fluorescence (XRF) and Scanning Electron Microscopy (SEM). ICP-AES, XRF and SEM-EDX are usually applied to analysis the major elements present in the sample (Nunes et al., 2016).

\section{Treatment of $A M D$}

The experimental tank was designed with silica glass materials $(18 \times 17.5 \times 17.5)$. Each tank was set up with 5 liters of synthetic water. The synthetic solutions contain of high concentrations of $\mathrm{Fe}(\mathrm{II}), \mathrm{Mn}, \mathrm{Pb}(\mathrm{II}), \mathrm{Cu}(\mathrm{II}), \mathrm{Zn}$ (II), $\mathrm{Cd}(\mathrm{II})$ and $\mathrm{Ni}(\mathrm{II})$ for 251, 572, 561, 840, 753, 647 and 754 $\mathrm{mg} / \mathrm{L}$ respectively with initial $\mathrm{pH}$ at 2.4 . Only four types of adsorbents used for treatment process except kaolinite due to treatment weaknesses. Adsorbents were weighed out for $100 \mathrm{~g}$ and put into cotton pot before ready for treatment process. The tanks were run by magnetic stirrer FAVORIT with 200 rpm nonstop for 30 days.

\section{Results}

\section{Characterization of AMD Samples}

Table 2 indicates the results of $\mathrm{pH}$, conductivity (EC), potential production (Eh), Temperature (T), Total Dissolved Solid (TDS), Dissolved Oxygen (DO) and salinity. Field data of AMD is in acidic phases at pH 2.81-4.16 for Kampung Aur, Sungai Lembing and Chini respectively. The highest reading of D.O was recorded at $\mathrm{Kg}$. Besul at $10.06 \mathrm{mg} / \mathrm{L}$ and the lowest value recorded at $\mathrm{Kg}$. Aur $(7.45 \mathrm{mg} / \mathrm{L})$. The value of D.O for water pollution index in clean water class $\mathrm{V}$ is more than $1 \mathrm{mg} / \mathrm{L}$ and all mining sites were considered safe due to the value of dissolved oxygen. 
Table 2: In situ water quality parameters of mine water

\begin{tabular}{llllllll}
\hline Mining Sites & Temp. $\left({ }^{\circ} \mathrm{C}\right)$ & $\mathrm{pH}$ & $\mathrm{DO}(\mathrm{mg} / \mathrm{L})$ & $\mathrm{Eh}(\mathrm{mV})$ & Salinity & Conductivity $(\mu \mathrm{s} / \mathrm{cm})$ & $\mathrm{TDS}(\mathrm{g} / \mathrm{L})$ \\
\hline Bukit Ibam & 29.6 & 7.90 & 8.44 & -37.7 & 0.65 & 911.67 & 0.84 \\
Kg. Aur (Upper) & 29.9 & 2.81 & 7.45 & 244.0 & 1.46 & 1699.67 & 1.57 \\
Kg. Aur (Lower) & 28.9 & 3.17 & 7.40 & 233.1 & 0.88 & 1166.00 & 1.12 \\
Chini & 29.7 & 4.16 & 8.05 & 195.8 & 0.20 & 312.00 & 0.27 \\
Sungai Lembing & 29.6 & 3.60 & 8.36 & 153.0 & 0.09 & 135.33 & 0.12 \\
Kuari JKR Kg. Awah & 33.3 & 7.89 & 9.27 & -37.4 & 0.16 & 260.00 & 0.22 \\
Kuari Kota Gelanggi & 33.5 & 7.66 & 8.14 & -31.1 & 0.15 & 218.00 & 0.20 \\
Kg. Besul & 31.3 & 7.61 & 10.06 & -20.6 & 0.33 & 485.67 & 0.43 \\
Selinsing & 31.6 & 6.60 & 8.08 & -16.7 & 0.32 & 438.00 & 0.43 \\
Batu Malim & 35.8 & 7.46 & 7.47 & -19.0 & 0.04 & 67.00 & 0.06 \\
\hline
\end{tabular}

The potential production (Eh) showed a high value were recorded at Kg. Aur, Chini and Sungai Lembing (153.0, 195.8 and $244.0 \mathrm{mV}$ ) respectively while electrical conductivity was recorded between 438.0 to $1699.67 \mu \mathrm{s} / \mathrm{cm}$ in some places respectively. Table 3 illustrates the average of concentration of heavy metals such as $\mathrm{Pb}, \mathrm{Cd}, \mathrm{Zn}, \mathrm{Cu}$, $\mathrm{Mn}, \mathrm{Cr}, \mathrm{Ni}$ and As obtained from all mining sites and calculated concentration is shown in Fig. 1. The concentration of lead, $\mathrm{Pb}(\mathrm{II})$ found very high at $\mathrm{Kg}$. Aur upper $(0.215 \mathrm{mg} / \mathrm{L})$ while the concentration of cadmium and zinc were highest recorded at Sungai Lembing (0.047 and $5.07 \mathrm{mg} / \mathrm{L}$ respectively). AMD was strongly acidic and contained significant levels of metal ions, especially Fe.

The acidic characteristic of the AMD results from the percolation of water through sulfide minerals generally pyrite, which oxidizes and dissociates when in contact with air and water. The concentration of $\mathrm{Fe}$ was found very high at $\mathrm{Kg}$ Aur (bottom part) of $202.69 \mathrm{mg} / \mathrm{L}, \mathrm{Kg}$ Aur (upper part) of $129.43 \mathrm{mg} / \mathrm{L}$, while the lowest content of Fe found at Batu Malim of $0.05 \mathrm{mg} / \mathrm{L}$. There were no significant differences between mine waters for the concentration of kalium while other metals $(\mathrm{Pb}, \mathrm{Zn}, \mathrm{Cr}$, $\mathrm{Cd}, \mathrm{Cu}, \mathrm{Ni}$ and $\mathrm{As}$ ) show significantly differences in terms of concentration. The lead and chromium exceeded for concentration of standard WQA 2000 in Kg. Aur, Sungai Lembing, Selinsing and Chini and the concentration of cadmium in Sungai Lembing exceeded the standard too. The content of heavy metal at Kg. Aur and Sungai Lembing displays very low concentration of $\mathrm{Cu}$ but high content of $\mathrm{Mn}$. The mean values for $\mathrm{Mn}$ was higher at Chini with concentration of $36.91 \mathrm{mg} / \mathrm{L}$. The anion values of sulfate were found maximum at lower part of $\mathrm{Kg}$ Aur $(5180.86 \mathrm{mg} / \mathrm{L})$ while very minimum at Cheroh $(20.22$ $\mathrm{mg} / \mathrm{L})$. Meanwhile for chloride was found very high at lower part of $\mathrm{Kg}$ Aur $(48.56 \mathrm{mg} / \mathrm{L})$ but the concentration at Sungai Lembing was very low $(1.21 \mathrm{mg} / \mathrm{L})$.

\section{AMD Prediction}

Table 4 lists AMD prediction results using acid-base accounting method for each mine sites. The values of $\mathrm{pH}$ identified the host rock of each mining sites. $\mathrm{Kg}$. Aur has $\mathrm{pH}$ value 2.34 which host rock is hematite and Chini with $\mathrm{pH}$ value of 2.00 which host rock is manganese. Only five mining sites have sulfur content which are Bukit Ibam, Kg. Aur, Chini, Selinsing and Sungai Lembing with total values of APP of $22.86 \mathrm{~kg}$ $\mathrm{CaCO}_{3} /$ ton, $50.79 \mathrm{~kg} \mathrm{CaCO}_{3} /$ ton, $924.27 \mathrm{~kg} \mathrm{CaCO}_{3} /$ ton, $22.84 \mathrm{~kg} \mathrm{CaCO}_{3} /$ ton and $2500.16 \mathrm{~kg} \mathrm{CaCO}_{3} /$ ton respectively. Analyses of rock samples from other sites which are JKR Kg. Awah, Kota Gelanggi, Kg. Besul and Gelanggi have not detected any sulfur content. From total sulfur analysis, the highest value of total sulfur content recorded at Sungai Lembing which are $2500.16 \mathrm{~kg}$ $\mathrm{CaCO}_{3} /$ ton. The amount of neutralizing bases, including carbonates, present in overburden materials is found by treating a sample with a known excess of standardized hydrochloric acid (Smith et al., 1974). The values of Neutralizing Potential (NP), obtained from the titration test in decreasing order, Chini $>$ Bukit Ibam $>\mathrm{Kg}$ Aur $>$ Selinsing $>$ Sungai Lembing were calculated as $337.43 \mathrm{~kg}$ $\mathrm{CaCO}_{3} /$ ton, $159.63 \mathrm{~kg} \mathrm{CaCO}_{3} /$ ton, $41.18 \mathrm{~kg} \mathrm{CaCO}_{3} /$ ton, $13.38 \mathrm{~kg} \mathrm{CaCO}_{3} /$ ton and $7.32 \mathrm{~kg} \mathrm{CaCO}_{3} /$ ton respectively. Meanwhile the classification of acid-bases for rock walls were found at low values of NP/APP at Kg. Aur, Chini, Selinsing and Sungai Lembing of 0.81, 0.37, 0.59 and 0.003 respectively as summarized in Fig. 2 .

\section{Toxicity of Tailing and Soil}

The Toxicity Characteristic Leaching Procedure (TCLP) test is used to determine the mobility of toxic contaminants present in waste materials and to define hazardous wastes under the Resource Conservation and Recovery Act (RCRA), 1984). The results from TCLP experiment showed that the concentration of As leached from sediment in the $\mathrm{Kg}$. Aur bottom samples after an $18 \mathrm{~h}$ extraction time was $7.955 \mathrm{mg} / \mathrm{L}$, which is exceeding the current maximum US EPA TCLP value for As. This would be characterized as a hazardous waste. The comparison of the sample between sediment in the Kampung Aur (bottom part) and tailing in the Sungai Lembing show different result of TCLP.

Table 5 identified heavy metals content with the highest concentration of $\mathrm{Pb}(17.42 \mathrm{mg} / \mathrm{L})$ at Sungai Lembing tailing and the lowest concentration found at Kg. Aur (bottom part), which is $1.21 \mathrm{mg} / \mathrm{L}$. The concentration of $\mathrm{Cd}$ found in Sungai Lembing tailing was $1.3 \mathrm{mg} / \mathrm{L}$ and soil in Sungai Lembing showed below the limitation value of concentration. 
Table 3: The concentration values of heavy metals in mine water as compared to EQA and WQS standard

\begin{tabular}{|c|c|c|c|c|c|c|c|c|c|c|c|c|}
\hline Locality/symbol & 1 & 2 & 3 & 4 & 5 & 6 & 7 & 8 & 9 & 10 & $\begin{array}{l}\text { Environment } \\
\text { quality act }\end{array}$ & $\begin{array}{l}\text { Water } \\
\text { quality } \\
\text { standard }\end{array}$ \\
\hline Element $(\mathrm{mg} / \mathrm{L})$ & Kg Aur & Kg Aur & Sungai & Selinsing & Chini & Kg. & Kuari Kota & Kuari Kg & Bukit & Batu & EQA & WQS \\
\hline Locality & Upper & Bottom & Lembing & & & Besul & Gelanggi & Awah & Ibam & Malim & 1997 & 2000 \\
\hline $\mathrm{Pb}$ average & 0.215 & 0.028 & 0.102 & 0.031 & 0.040 & 0.000 & 0.000 & 0.000 & 0.0002 & 0.000 & 0.1 & 0.01 \\
\hline $\mathrm{n}=9$ & $\begin{array}{l}0.199- \\
0.22)\end{array}$ & $\begin{array}{l}(0.027- \\
0.032)\end{array}$ & $\begin{array}{l}(0.098- \\
0.103)\end{array}$ & $\begin{array}{l}(0.024- \\
0.035)\end{array}$ & $\begin{array}{l}(0.037- \\
0.047)\end{array}$ & $(-)$ & $(-)$ & $(-)$ & $\begin{array}{l}(0-0 . \\
004)\end{array}$ & $(-)$ & & \\
\hline $\mathrm{Cd}$ & 0.022 & 0.004 & 0.047 & 0.000 & 0.018 & 0.000 & 0.000 & 0.000 & 0.000 & 0.000 & - & 0.03 \\
\hline $\begin{array}{l}\text { Average } \\
\mathrm{n}=9\end{array}$ & $\begin{array}{l}(0.012- \\
0.025)\end{array}$ & $\begin{array}{l}(0.004- \\
0.004)\end{array}$ & $\begin{array}{l}(0.044- \\
0.05)\end{array}$ & $(-)$ & $\begin{array}{l}(0.015- \\
0.019)\end{array}$ & $(-)$ & $(-)$ & $(-)$ & $(-)$ & $(-)$ & & \\
\hline $\mathrm{Zn}$ & 1.005 & 0.557 & 5.070 & 0.783 & 1.685 & 0.007 & 0.001 & 0.000 & 0.012 & 0.004 & 2.0 & 0.3 \\
\hline $\begin{array}{l}\text { Average } \\
\mathrm{n}=9\end{array}$ & $\begin{array}{l}(0.998- \\
1.00)\end{array}$ & $\begin{array}{l}(0.483- \\
0.613)\end{array}$ & $\begin{array}{l}(4.77- \\
5.554)\end{array}$ & $\begin{array}{l}(0.566- \\
0.845)\end{array}$ & $\begin{array}{l}(0.999- \\
1.037)\end{array}$ & $\begin{array}{l}(0.002- \\
0.001)\end{array}$ & $\begin{array}{l}(0.0005- \\
0.001)\end{array}$ & $(-)$ & $\begin{array}{l}(0.006- \\
0.021)\end{array}$ & $\begin{array}{l}(0.002- \\
0.008)\end{array}$ & & \\
\hline $\mathrm{Cu}$ & 1.185 & 1.065 & 5.232 & 0.000 & 0.154 & 0.003 & 0.004 & 0.003 & 0.005 & 0.000 & 0.2 & - \\
\hline Average & $(0.988$ & $(0.999$ & $(4.978$ & $(-)$ & $(0.138$ & $(0.002$ & $(0.002$ & $(0.001$ & $(0.0006$ & $(-)$ & & \\
\hline$n=9$ & $-1.100)$ & $-1.117)$ & $-5.55)$ & & $-0.197)$ & $-0.001)$ & $-0.006)$ & $-0.005)$ & $-0.010)$ & & & \\
\hline $\mathrm{Mn}$ & 2.157 & 3.802 & 10.945 & 2.778 & 36.914 & 0.024 & 0.001 & 0.006 & 0.536 & 0.052 & - & 0.1 \\
\hline Average & $(1.922$ & $(3.335$ & $(10.14$ & $(2.111$ & $(33.58$ & $(0.015$ & $(0.001$ & $(0.001$ & $(0.532$ & $(0.027$ & & \\
\hline $\mathrm{n}=9$ & $-2.00)$ & $-4.074)$ & $-11.70)$ & $-2.34)$ & $-39.24)$ & $-0.031)$ & $-0.001)$ & $-0.011)$ & $-0.556)$ & $-0.068)$ & & \\
\hline $\mathrm{Cr}$ & 0.026 & 0.031 & 0.0182 & 0.029 & 0.009 & 0.010 & 0.023 & 0.010 & 0.017 & 0.171 & 0.05 & 0.05 \\
\hline Average & $(0.015$ & $(0.025$ & $(0.013$ & $(0.019$ & $(0.006$ & $(0.001$ & $(0.016$ & $(0.005$ & $(0.005$ & $(0.163$ & & \\
\hline $\mathrm{n}=9$ & $-0.029)$ & $-0.048)$ & $-0.027)$ & $-0.033)$ & $-0.012)$ & $-0.016)$ & $-0.036)$ & $-0.015)$ & $-0.042)$ & $-0.177)$ & & \\
\hline $\mathrm{Ni}$ & 0.036 & 0.038 & 0.126 & 0.169 & 0.025 & 0.005 & 0.007 & 0.002 & 0.011 & 0.014 & 0.2 & - \\
\hline Average & $(0.026$ & $(0.034$ & $(0.120$ & $(0.13$ & $(0.022$ & $(0$ & $(0.005$ & $(0.002$ & $(0.008$ & $(0.008$ & & \\
\hline $\mathrm{n}=9$ & $-0.037)$ & $-0.041)$ & $-0.131)$ & $-0.177)$ & $-0.027)$ & $-0.008)$ & $-0.012)$ & $-0.003)$ & $-0.011)$ & $-0.018)$ & & \\
\hline As & 0.003 & 0.002 & 0.002 & 0.005 & 0.003 & 0.000 & 0.001 & 0.001 & 0.001 & 0.000 & 0.05 & 0.01 \\
\hline Average & $(0.001$ & $(0.001$ & $(0.002$ & $(0.002$ & $(0.002$ & $(-)$ & $(0-0$ & $(0.0005$ & $(0.001$ & $(-)$ & & \\
\hline$n=9$ & $-0.004)$ & $-0.002)$ & $-0.002)$ & $-0.006)$ & $-0.003)$ & & $.001)$ & $-0.001)$ & $-0.001)$ & & & \\
\hline $\mathrm{Ca}$ & 12.752 & $0.000^{\prime}$ & 4.882 & 49.462 & 1.010 & 34.031 & 18.919 & 16.385 & 51.728 & 2.276 & - & - \\
\hline $\mathrm{Mg}$ & 8.584 & 93.755 & 2.813 & 27.478 & 0.4133 & 9.128 & 9.159 & 10.707 & 56.029 & 5.346 & - & - \\
\hline $\mathrm{K}$ & 1.738 & 7.861 & 0.584 & 3.531 & 1.9275 & 1.685 & 0.3003 & 0.475 & 10.992 & 0.836 & - & - \\
\hline $\mathrm{Na}$ & 2.501 & 15.788 & & 11.512 & 1.710 & 25.224 & 0.633 & 6.742 & 3.987 & 90.092 & - & - \\
\hline $\mathrm{Fe}$ & 129.433 & 202.69 & 1.203 & 0.203 & 0.269 & 0.364 & 0.345 & 0.142 & 0.525 & 0.050 & 1.0 & 0.3 \\
\hline & (115.20 & (180.82 & $(0.974$ & $(0.156$ & $(0.188$ & $(0.27$ & $(0.29$ & $(0.118$ & $(0.488$ & $(0.032$ & & \\
\hline $\mathrm{n}=9$ & $-130.00)$ & $-213.47)$ & $-1.532)$ & $-0.244)$ & $-0.984)$ & $-0.700)$ & $-0.77)$ & $-0.165)$ & $-0.579)$ & $-0.060)$ & & \\
\hline $\mathrm{SO}_{4}{ }^{-2}$ & 3179.6 & 5180.86 & 75.67 & 247.89 & 48.94 & 220.52 & 87.58 & 65.86 & 718.69 & 20.22 & 0.5 & 250 \\
\hline $\mathrm{Cl}^{-}$ & 21.52 & 48.56 & 1.21 & 3.68 & 2.36 & 9.02 & 4.26 & 2.38 & 6.39 & 1.5 & 2. & 250 \\
\hline
\end{tabular}

Table 4: The AMD prediction results of Acid-Base Accounting method for each mine sites

\begin{tabular}{lllllll}
\hline Locality & $\begin{array}{l}\text { Total of } \mathrm{APP} \\
\left(\mathrm{kg} \mathrm{CaCO}_{3} / \text { ton }\right)\end{array}$ & $\begin{array}{l}\text { Total of NP } \\
\left(\mathrm{kg} \mathrm{CaCO}_{3} / \text { ton }\right)\end{array}$ & $\begin{array}{l}\mathrm{NPP} \\
(\mathrm{NP}-\mathrm{APP})\end{array}$ & $\mathrm{NP} / \mathrm{APP}$ & $\mathrm{pH}$ & Samples \\
\hline Bukit Ibam & 22.86 & 159.63 & 136.77 & 6.98 & 8.00 & Ore \\
Kg. Aur & 50.79 & 41.18 & -9.61 & 0.81 & 2.34 & Hematite \\
Chini & 924.27 & 337.43 & -586.84 & 0.37 & 2.00 & Manganese \\
Selinsing & 22.84 & 13.38 & -9.46 & 0.59 & 7.90 & Slate \\
Sungai Lembing & 2500.16 & 7.32 & -2492.84 & 0.003 & 2.90 & Tailings \\
\hline
\end{tabular}

Table 5: The concentration of $\mathrm{As}, \mathrm{Cd}, \mathrm{Cr}$ and $\mathrm{Pb}$ for TCLP test

\begin{tabular}{lllll}
\hline TCLP & Sungai Lembing soil $(\mathrm{mg} / \mathrm{L})$ & Sungai Lembing Tailing $(\mathrm{mg} / \mathrm{L})$ & Kg. Aur bottom $(\mathrm{mg} / \mathrm{L})$ & USEPA $(\mathrm{mg} / \mathrm{L})$ \\
\hline Arsenic & 1.86 & 0.814 & 7.955 & 5 \\
Cadmium & 0.319 & 1.3 & 0.096 & 1 \\
Chromium & 0.213 & 0.35 & 0.223 & 5 \\
Lead & 3.864 & 17.417 & 1.207 & 5 \\
\hline
\end{tabular}

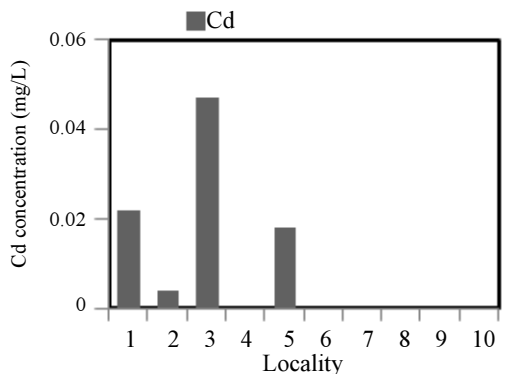

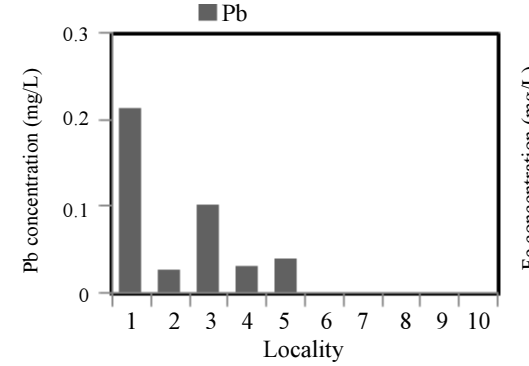

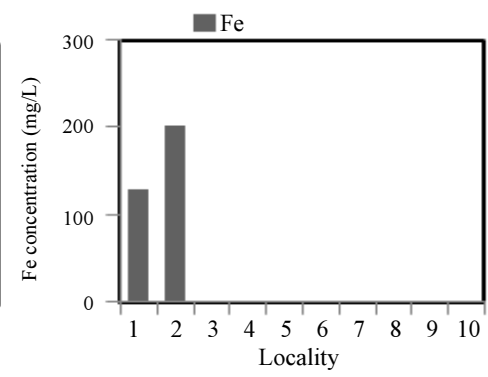



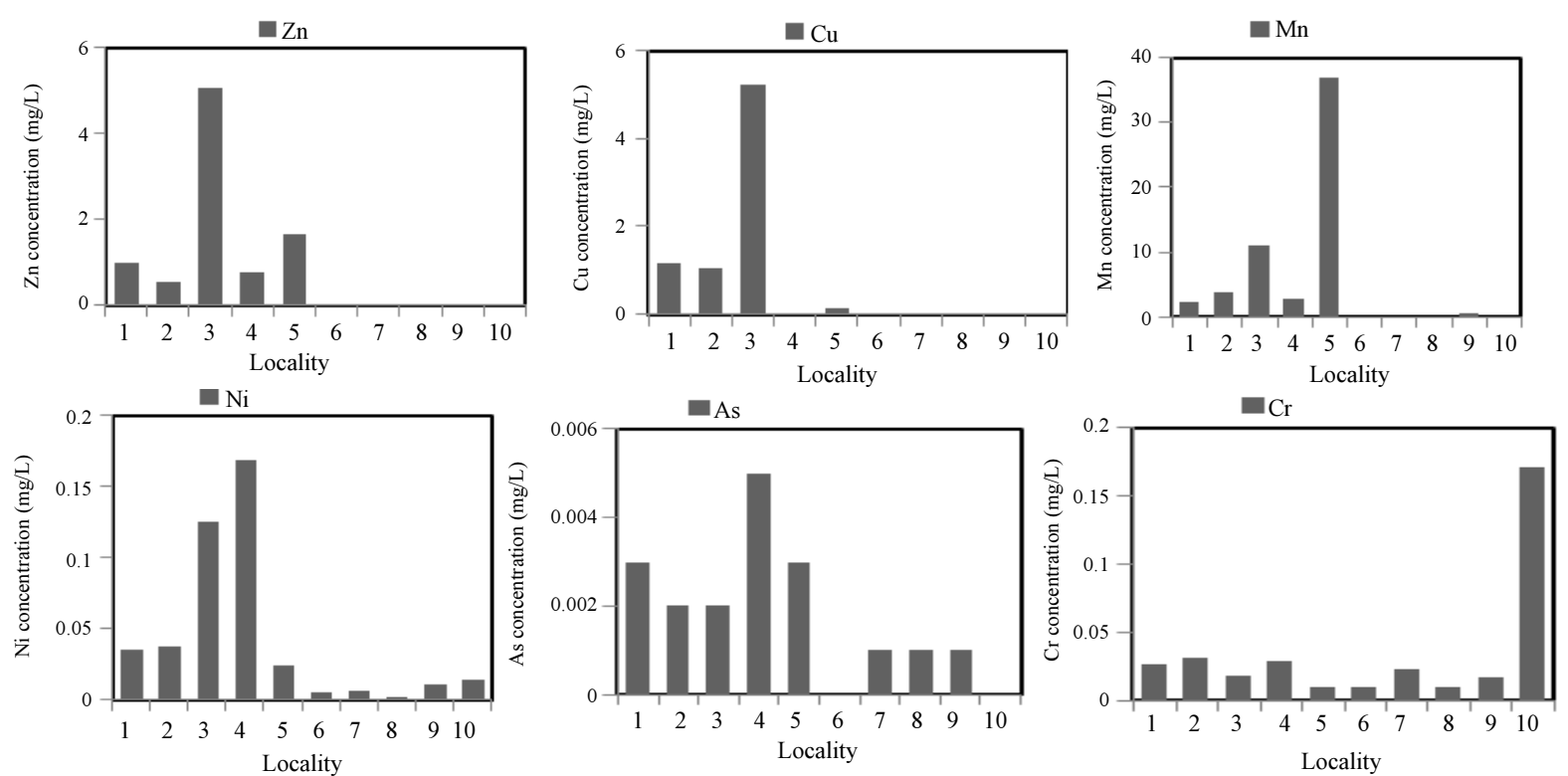

Fig. 1: The concentration values of heavy metals $(\mathrm{mg} / \mathrm{L})$ for each locality

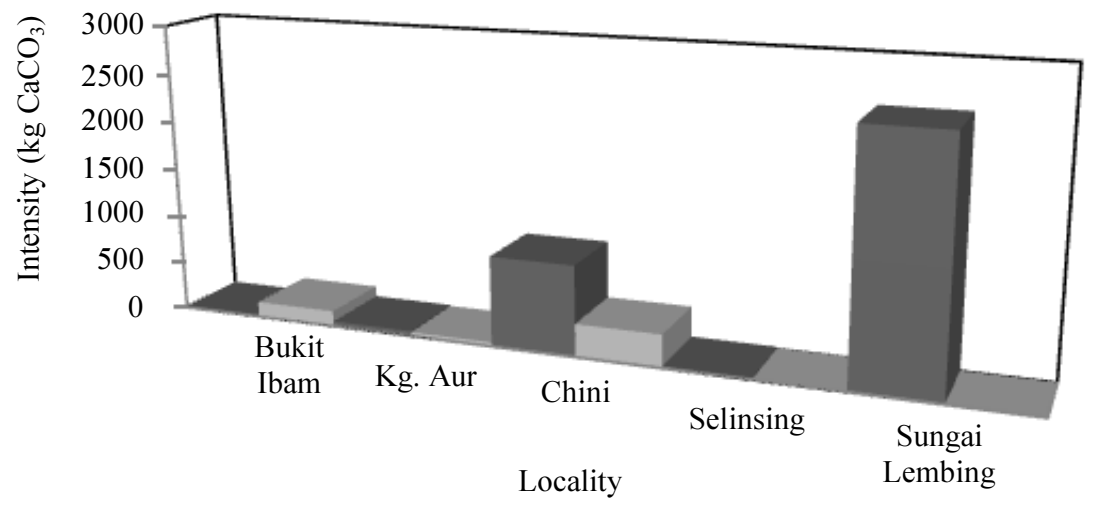

Fig. 2: The concentration of NP and APP for each locality

\section{Characterization of Treatment Material}

The major elements from treatment test are analyzed by XRF. Table 6 summarized LFS has the highest percentage of $\mathrm{CaO}$ which is $52.86 \%$, while bentonite, zeolite and kaolinite contained of highest percentage of $\mathrm{SiO}$ of $53.00 \%, 65.23 \%$ and $77.99 \%$ respectively. Active carbon showed a very lowest value of elemental phases $(<$ 5\%). XRF analysis showed the lowest elemental composition of LFS was $\mathrm{SiO}(5.93 \%)$ while bentonite and zeolite showed the similar lowest elemental composition which is $\mathrm{Fe}_{2} \mathrm{O}_{3}$ of 2.88 and $2.66 \%$ respectively. Figure 3 identified SEM images of LFS, bentonite, zeolite and active carbon. SEM image of LFS is characterized by large clusters of radiating tetragonal prisms cemented together with homogeneous particles with rough surfaces. SEM images of bentonite and zeolite characterized by similar platy textures in different particle sizes. SEM image of active carbon showed a rough and nonhomogeneous structures with size of particles ranging from 1 mikrometer to 100 mikrometer. Figure 3 were SEM images for (a) ladle furnace slag (magnification 500x) (b) bentonit (magnification 500x) (c)active carbon (magnification 500x) and (d)zeolite (magnification 2000x).

\section{Effect of $\mathrm{pH}$}

The variations of $\mathrm{pH}$ values with time identified as Fig. 4. The synthetic solution present low $\mathrm{pH}$ values approximately 2.39-2.4 at the beginning. At the beginning, LFS analysis showed significantly increase of $\mathrm{pH}$ value (4.35) while other adsorbents showed slightly increase 2.41-2.71. High content of $\mathrm{CaO}$ in LFS increased the alkalinity of solution. Moreover, at days 30 , synthetic solution contains LFS showed nearly to neutral $\mathrm{pH}$ (6.11) compared to others which are bentonite 3.91), active carbon (2.98) and zeolite (2.71) still in acidic phases respectively. 
Nur Athirah Mohamad Basir et al. / American Journal of Engineering and Applied Sciences 2019, 12 (2): 173.184 DOI: $10.3844 /$ ajeassp.2019.173.184

Table 6: Major element for treatment materials

\begin{tabular}{|c|c|c|c|c|c|}
\hline Major element (\%) & LFS & Bentonite & Zeolite & Kaolinite & Active Carbon \\
\hline $\mathrm{SiO}_{2}$ & 5.93 & 53.00 & 65.23 & 77.90 & 2.34 \\
\hline $\mathrm{TiO}_{2}$ & 0.15 & 0.34 & 0.42 & 0.55 & n.a \\
\hline $\mathrm{Al}_{2} \mathrm{O}_{3}$ & 26.92 & 16.91 & 12.15 & 13.00 & n.a \\
\hline $\mathrm{Fe}_{2} \mathrm{O}_{3}$ & 1.22 & 2.88 & 2.66 & 0.98 & 0.27 \\
\hline $\mathrm{MnO}$ & 0.04 & 0.01 & 0.04 & 0.01 & 0.02 \\
\hline $\mathrm{MgO}$ & 7.73 & 3.06 & 0.83 & 0.31 & 0.12 \\
\hline $\mathrm{CaO}$ & 54.86 & 2.09 & 3.55 & 0.19 & 1.91 \\
\hline $\mathrm{Na}_{2} \mathrm{O}$ & 0.05 & 1.51 & 1.44 & 0.05 & 0.02 \\
\hline $\mathrm{K}_{2} \mathrm{O}$ & 0.08 & 0.36 & 0.93 & 1.67 & 1.99 \\
\hline $\mathrm{P}_{2} \mathrm{O}_{5}$ & 0.01 & 0.04 & 0.04 & 0.03 & 0.07 \\
\hline L.O.I & 0.32 & 21.45 & 14.30 & 4.80 & 4.17 \\
\hline Jumlah & 95.30 & 101.70 & 101.60 & 99.65 & - \\
\hline
\end{tabular}

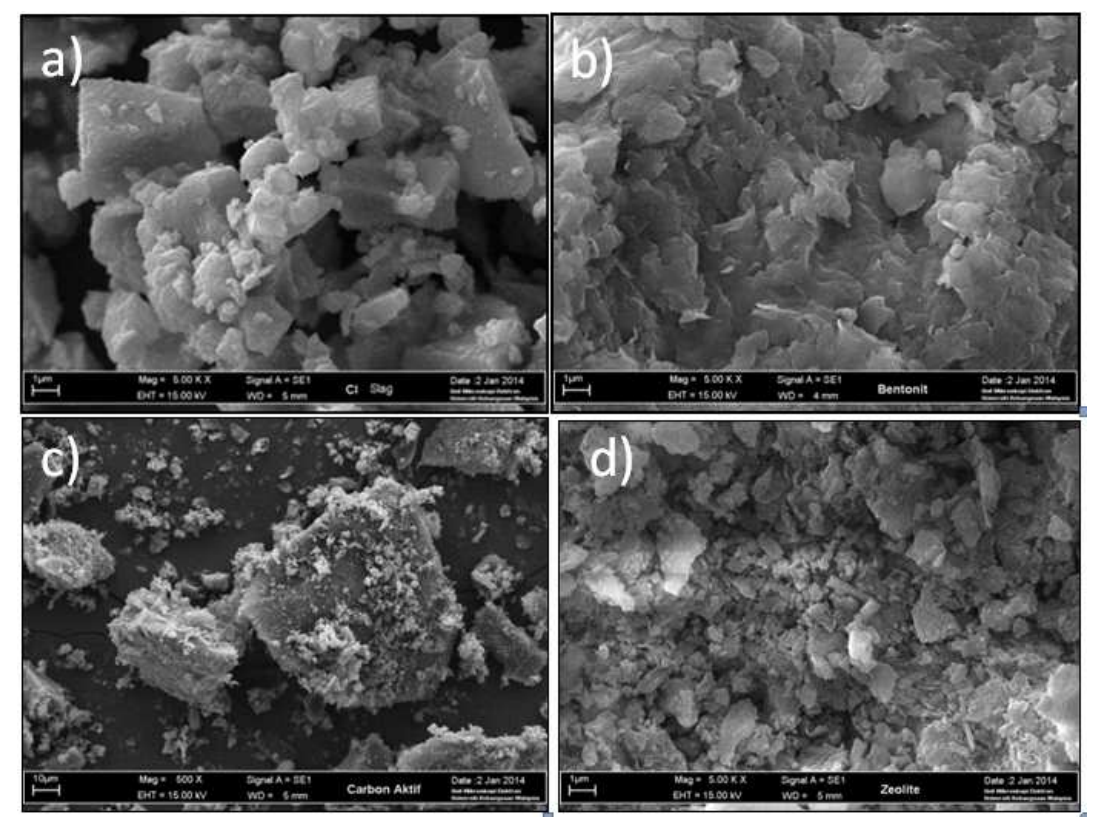

Fig. 3: SEM images for (a) ladle furnace slag (magnification 500×) (b) bentonite (magnification 500×) (c) active carbon (magnification 500x) and (d) zeolite (magnification 2000×)

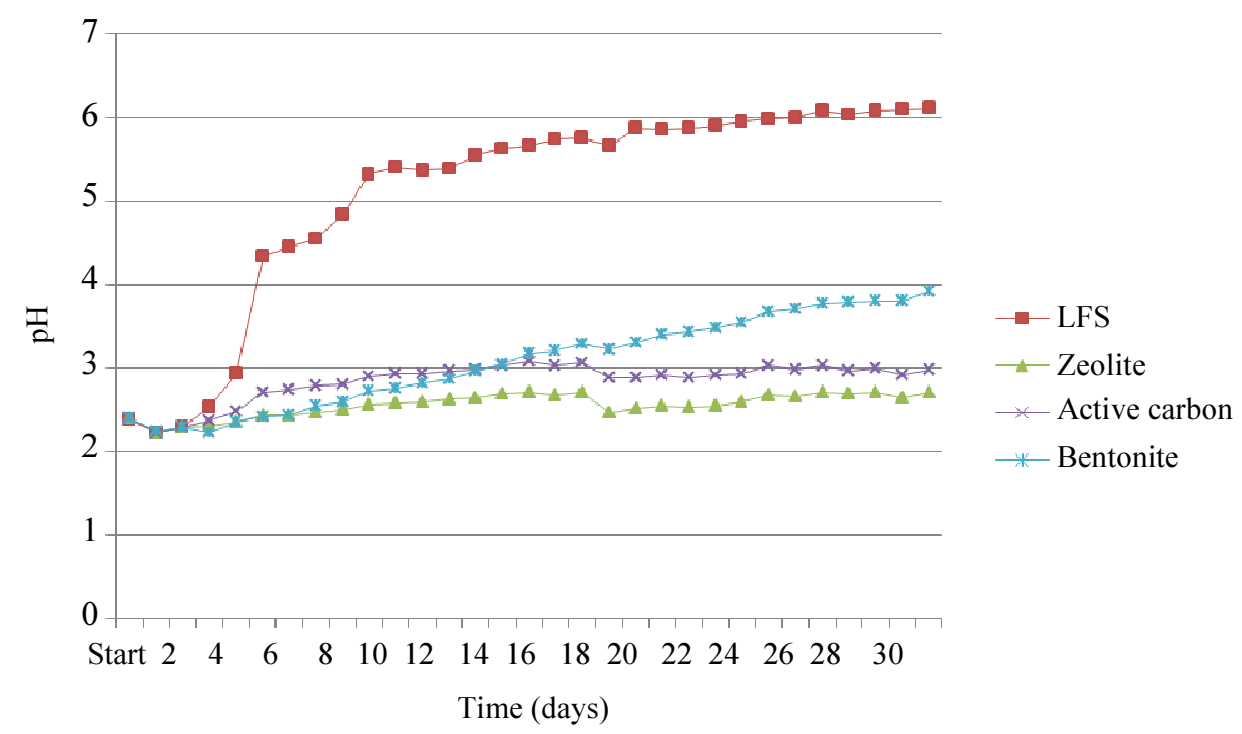

Fig. 4: The variations of $\mathrm{pH}$ values of LFS, bentonite, active carbon and zeolite during stirring tank operation for 30 days 

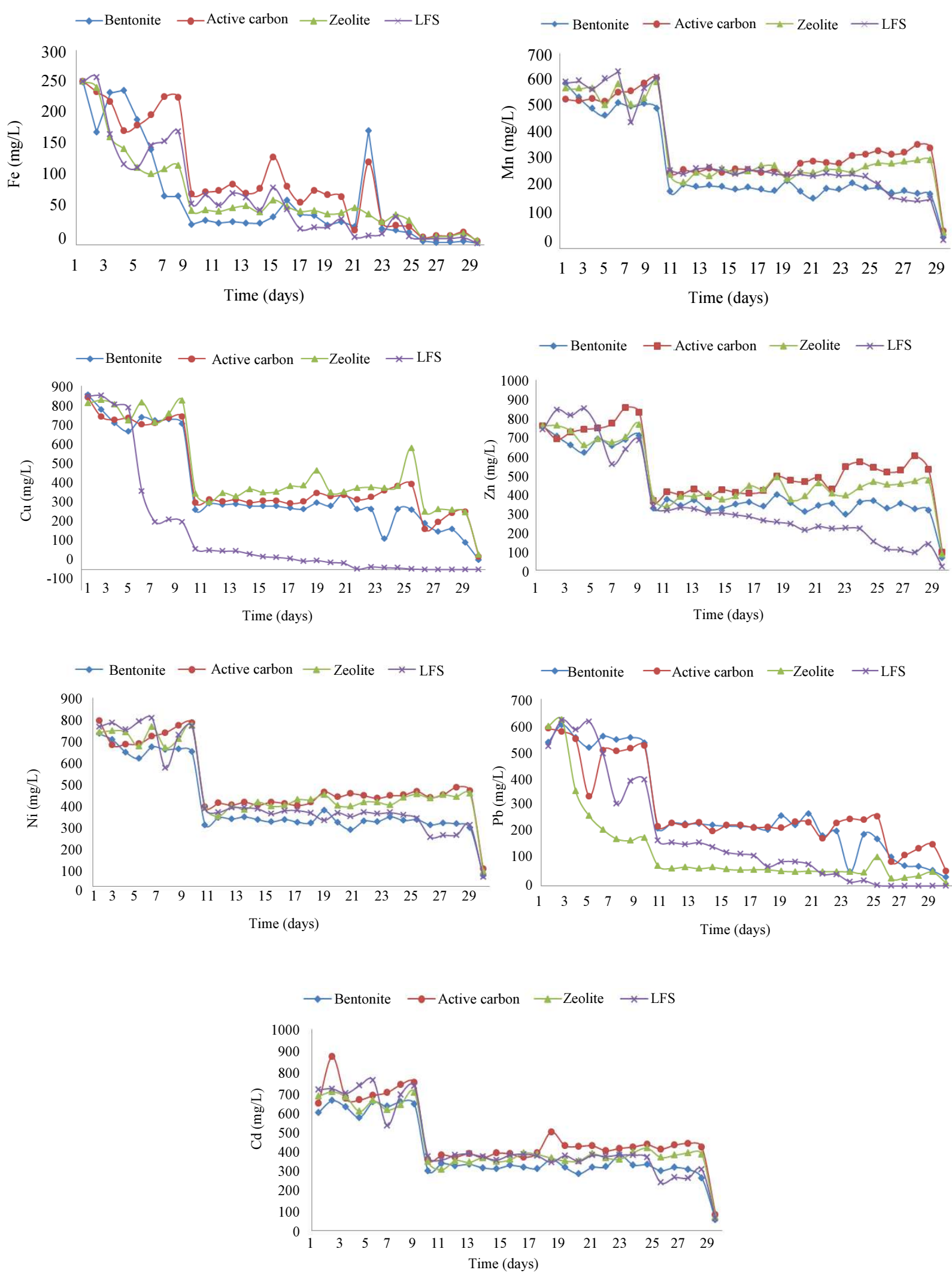

Fig. 5: Variation of $\mathrm{Cd}, \mathrm{Fe}, \mathrm{Mn}, \mathrm{Cu}, \mathrm{Zn}, \mathrm{Pb}$ and $\mathrm{Ni}$ concentrations during stirring tank operation for 30 days 


\section{Removal of Metals from Tank Experiment}

Figure 5 indicates the concentration of heavy metals with respect to time in the effluents from stirring tank. The pattern of heavy metals removal were decreasing through time. At the end of the tank experiment showed $\mathrm{Fe}$ concentration decreased from initial concentration of 251.34 to $5.84 \mathrm{mg} / \mathrm{L}$ (bentonite), $11.26 \mathrm{mg} / \mathrm{L}$ (LFS), $17.27 \mathrm{mg} / \mathrm{L}$ (zeolite) and 19.74 $\mathrm{mg} / \mathrm{L}$ (active carbon) respectively. Mn concentration were decreased from initial concentration of 572.63 $\mathrm{mg} / \mathrm{L}$ to $176.35 \mathrm{mg} / \mathrm{L}$ (LFS), $192.24 \mathrm{mg} / \mathrm{L}$ (bentonite), $313.90 \mathrm{mg} / \mathrm{L}$ (zeolite) and $360.44 \mathrm{mg} / \mathrm{L}$ (active carbon). The initial concentration of $\mathrm{Cu}$ decreased from $840.19 \mathrm{mg} / \mathrm{L}$ to $0.40 \mathrm{mg} / \mathrm{L}$ (LFS), $132.02 \mathrm{mg} / \mathrm{L}$ (bentonite), $278.60 \mathrm{mg} / \mathrm{L}$ (zeolite) and $281.49 \mathrm{mg} / \mathrm{L}$ (active carbon). For $\mathrm{Zn}$, the initial concentration decreased from 753.77 to $138.14 \mathrm{mg} / \mathrm{L}$ (LFS), 316.98 $\mathrm{mg} / \mathrm{L}$ (bentonite), $473.04 \mathrm{mg} / \mathrm{L}$ (zeolite) and 529.42 $\mathrm{mg} / \mathrm{L}$ (active carbon), while the concentration of $\mathrm{Pb}$ decreased from 561.58 to $0.41 \mathrm{mg} / \mathrm{L}$ (LFS), 51.77 $\mathrm{mg} / \mathrm{L}$ (bentonite), $56.92 \mathrm{mg} / \mathrm{L}$ (zeolite) and 154.74 $\mathrm{mg} / \mathrm{L}$ (active carbon) respectively.

\section{Discussion}

Based on the result in Table 2, the $\mathrm{pH}$ values recorded very low at $\mathrm{Kg}$ Aur, Chini and Sungai Lembing. Meanwhile, Kg. Aur, Chini and Sungai Lembing have the highest value of Eh showed solution that accept more proton and undergoes an oxidation process. According to Sangita and Bably (2010), the low $\mathrm{pH}$ of discharge mine water results in the further dissolution of minerals and release of toxic metals, when it allowed getting discharge into other water bodies. The value of $\mathrm{pH}$ can be as low as 2 and continues to be an important water pollution problem in mining industry around the world (Tsukamoto and Miller, 2004; Sangita and Bably, 2010). The conductivity of the water in the studied was found high. This high conductivity in the water is an indication of its effect on the water quality. Changes in conductivity were not always coincident with changes in $\mathrm{Eh}$ and $\mathrm{pH}$, indicating that conductivity may be a more sensitive tool for locating specific zones focus on sulfate reducing bacteria activity (Lyew and Sheppard, 2001). TDS indicates the general nature of water quality or salinity. Based on TDS classification, it can be said all water in the mining area except at Batu Malim where brackish water. Maximum value of sulfate ions at lower part of Kg. Aur exceeds WHO (2011) limited set at $250 \mathrm{mg} / \mathrm{L}$. For example, as a result of weathering of oxidized sulfide scarlet precipitation can be found up to a thousand meters from the AMD polluted river (Jennings et al., 2008). An excess of chloride ion in water is usually taken as an index of pollution. The high chloride content of water may have originated from natural sources such as rainfall and the dissolution of fluid inclusions.

$\mathrm{Fe}, \mathrm{Na}, \mathrm{K}, \mathrm{Ca}$ and $\mathrm{Mg}$ were the major cations for the current study and showed significant differences between all samples. Due to the lower $\mathrm{pH}$, the higher oxidation process, hence value of $\mathrm{Fe}$ will be higher. $\mathrm{Fe}$ was found highest in areas with low $\mathrm{pH}$ and found low in areas with high $\mathrm{pH}$. Hallberg (2010) stated due to the low $\mathrm{pH}$, the solubility of the toxic metals contained in the AMD keeps up at a high level thus permits their dispersion into the environment. The decreasing of $\mathrm{pH}$ could be attributed to the oxidation of $\mathrm{H}_{2} \mathrm{~S}$ and $\mathrm{Fe}(\mathrm{II})$. Calcium and sulfate concentration decreased as the precipitation proceeded. Precipitation using alkaline reagents for this research is the most widely used treatment method for removing metals as hydroxides (Johnson and Hallberg, 2005; Balintova and Petrilakova, 2011). The decrease in the chloride concentration probably could be ascribed due to the formation of some metal chloride. Thus, water reservoir in Chini has high value of Mn compared to others. Acidic water facilitates the movement of $\mathrm{Mn}$ that easily soluble in acidic condition. In another place, $\mathrm{pH}$ values closer to 9.0, manganese ions precipitate as manganese hydroxide, $\mathrm{Mn}(\mathrm{OH})_{2}$ allowing its removal (Da Silveira et al., 2009). The concentration of $\mathrm{Ni}$ and as were found safe for all water samples.

Prediction of AMD was calculated from APP and result recorded from Table 5. The value of NP/APP is below than 1, interpreted as high potential for acid production. Kg. Aur, Chini, Selinsing and Sungai Lembing have been identified as having high acid generation potential $\left(50.79-2500.16 \mathrm{~kg} \quad \mathrm{CaCO}_{3} /\right.$ ton $)$ compare to neutralization potential. ABA considers two factors, total $\mathrm{S}$ and $\mathrm{NP}$, assumed to represent $\mathrm{FeS}_{2}$ and $\mathrm{CaCO}_{3}$ (Sobek et al., 1978). Total S can consist sulfide, sulfate and organic sulfur components and acid can be produced by each of these. Pyrite generally is the acid producer and Cravotta (1991) have shown that the dissolution of iron and aluminium-sulfate minerals and the subsequent hydrolisis of iron and aluminium can produce substantial quantities of acidity. Harvey and Dollhopf (1986) have suggested that some forms of organic S also may be acid-producing. Although there were many pyrite minerals in the mining site of Bukit Ibam, AMD did not occur as they were naturally neutralized by calcite minerals. Previous studies in Penjom showed that drainage will remain neutral to basic if the rate of acid consumption equals or exceeds the rate of acid production (Mohd Syahrir and Seong, 2012). Smith and Brady (1990) evaluated if the value of NNP is less than zero, the acid-producing potential of the rock exceeds its neutralization potential and if mined, therefore would be expected to produce AMD. Four localities except Bukit Ibam showed negative values of NPP, then the potential exist for the waste to form acid as suggested by USEPA (1994). The values of ABA for Bukit Ibam have lower risk for the formation of acid mine drainage. Brodie et al. (1991) suggested if the ratio 
is greater than $3: 1$, experience indicates that there is lower risk for acid mine to develop, meanwhile samples with a ratio of $1: 1$ or less are potentially to generate acid.

From TCLP analysis, hazardous waste was identified at Sungai Lembing and Kg. Aur. This is due to the fact that As element in Sungai Lembing had high concentration that exceed the limitation. As concentration in tailing at Sungai Lembing and $\mathrm{Pb}$ in $\mathrm{Kg}$. Aur were mobile in characteristic. Exceed value concentration of TCLP element showed element was mobility and of great danger to environment. Hence, labeled as hazardous waste. The proportion of metals leached by the TCLP depends on a sludge's neutralization potential. A sludge with small neutralization potential is incapable of neutralizing all the acid added and the resultant low $\mathrm{pH}$ will cause a substantial proportion of the metals present to be leached (Danny and John, 2006).

The immobilization of heavy metal ions from aqueous solutions is quite a complicated process, consisting of ion exchange and adsorption and is likely to be accompanied by precipitation of metal hydroxide complexes on active sites of the particle surface (Rios et al., 2008). The removal of heavy metals from AMD using different types of adsorbent materials. All sorbents produced similar trends of removal the heavy metals with an abrupt decrease within 8 days. LFS is the best material for absorption of $\mathrm{Zn}, \mathrm{Mn}$ and $\mathrm{Cu}$ in the contaminated water followed by bentonite, zeolite and active carbon. Various researchers including Ziemkiewicz and Skousen (1998; Simmons et al., 2001; Ochola and Moo-Young (2005) have identified steel slag as a suitable candidate to remediate waters contaminated by Acid Mine Drainage (AMD), since it has been shown to have a significant acid neutralizing potential that can be exploited to precipitate out a majority of dissolved metals by increasing solution $\mathrm{pH}$. The Acid Neutralization Potential of steel slag was determined to be approximately $83 \%$ as calcium carbonate $\left(\mathrm{CaCO}_{3}\right)$ (Ochola and Moo-Young, 2005). Meanwhile, bentonit was the best to adsorb more $\mathrm{Ni}, \mathrm{Fe}$ and $\mathrm{Cd}$. The concentration of heavy metal was decreased greatly due to owning of precipitation, co-precipitation and huge absorbency. Therefore, the utilization of LFS can achieve the purpose to neutralize the high acidity, minimize the release of heavy metal and improve the water quality of drainage.

\section{Conclusion}

Analysis was done at the mine which has a watershed. Water is an important indicator to determine the level of acidity of mine drainage. Overall, $\mathrm{Kg}$ Aur, Cini and Sungai Lembing found very acidic with low $\mathrm{pH}$ and contain high concentration of heavy metals. Therefore, the acidity and neutralization test were applied for waste rock, tailings or soil at the mining site. Acid-base accounting showed the possibility of field sites to form and produce acid especially for Sungai Lembing with the highest value of APP. TCLP element was made to test the nature of mobility and thus labeled as hazardous waste. Sungai Lembing and Kg. Aur have hazardous waste of $\mathrm{Pb}$ and $\mathrm{As}$ elements respectively. The AMD levels are identified from low $\mathrm{pH}$ and sulfate ions or high of heavy metal. Supported by this static test, results showed that the potential mine suffered of excessive acid production. Overall, AMD identified from all these tests at $\mathrm{Kg}$ Aur, Sungai Lembing, Selinsing and Chini. The most dangerous among others is Sungai Lembing and if no action is made, it can affect surrounding area with high generation of acid potential. There are known treatment methods which can be applied before the AMD situation can worsen and consequently source river pollution. By conducting continuous tank experiment tests for about 30 days using synthetic solution prepared, it was found that by product material such as LFS and natural material such as bentonite can effectively adsorb and remove various heavy metals simultaneously. Besides, these adsorbents can also efficiently neutralize the acidic drainage due to its high alkalinity production by calcite dissolution.

\section{Acknowledgment}

The Author would like to express gratitude to the UKM for providing research laboratories and as well as Pahang state government where research is done.

\section{Author's Contributions}

Nur Athirah Mohamad Basir: Conducting the experimental work and drafting this paper

W.Y. Wan Zuhairi: Is the main supervisor of the study and revise the article.

Nuur Hani Mohammed, Mustapha Atta and Nur Aishah Zarime: Revise the article.

\section{Ethics}

This article is an original and contains unpublished materials. All authors have read and approved this manuscript and no ethical issues involved.

\section{References}

Abdelaal, A.M., 2004. Using a natural coagulant for treating wastewater. Proceedings of the 8 th International Water Technology Conference, (WTC' 04), Alexandria, Egypt, pp: 781-792.

Akcil, A. and S. Koldas, 2006. Acid mine drainage: Causes, treatment and case studies. J. Cleaner Prod., 14: 1139-1145. DOI: 10.1016/j.jclepro.2004.09.006 
Barrie, D. and B. Kevin, 2005. Acid mine drainage remediation options: A review. Sci. Total Environ., 338: 3-14.

Balintova, M. and A. Petrilakova, 2011. Study of pH influence of selective precipitation of heavy metals from acid mine drainage. Chem. Eng. Trans., 25: 1-6

Barakat, M.A., 2011. New trends in removing heavy metals from industrial wastewater. Arabian J. Chem., 4: 361-377.

Brodie, M.J., L.M. Broughton and A.M. Robertson, 1991. A conceptual rock classification system for waste management and a laboratory method for ARD prediction from rock piles. Proceedings of the International Conference on the Abatement of Acidic Drainage, Sept. 16-18, Montreal, Canada.

Coulton, R., C. Bullen and C. Hallet, 2003. The design and optimization of active mine water treatment plants. Land Contam Reclam., 11: 273-279.

Cravotta, C.A., 1991. Geochemical evolution of acidic ground water at a reclaimed surface coal mine in western Pennsylvania. Proceedings of the National Meeting of the American Society of Surface Mining and Reclamation, May 14-17, Durango, pp: 43-68.

Da Silveira, A.N., R. Silva and J. Rubio, 2009. Treatment of Acid Mine Drainage (AMD) in South Brazil. Int. J. Mineral Proc., 93: 103-109.

DOI: 10.1016/j.minpro.2009.06.005

Danny, M.M. and A.W. John, 2006. Chemical stability of acid rock drainage treatment sludge and implications for sludge management. Environ. Sci. Technol.

Dias, J.M., M.C.M. Alvim-Ferraz, M.F. Almeida and M. Sanchez-Polo, 2007. Waste materials for activated ' carbon preparation and its use in aqueous-phase treatment: A review. J. Environ. Manage., 85: 833-846.

Haider, M.Z., M. Vakili and D. Irvan, 2014. Waste material adsorbents for zinc removal from wastewater: A comprehensive review. Int. J. Chem. Eng., 2014: 13-13.

Hallberg, K.B., 2010. New perspectives in acid mine drainage microbiology. Hydrometallurgy, 104: 448-453.

Harvey, K.C. and D.J. Dollhopf, 1986. Acid production from organic sulfur, in acid minesoil reclamation advancements in the northern plains: Montana State University, Reclamation Research Publication, 86-01: 54-60.

Jennings, S.R., D.R. Neuman and P. S. Blicker, 2008. Acid Mine Drainage and Effects on Fish Health and Ecology: A Review. 1st Edn., Reclamation Research Group, Bozeman, pp: 52.

Jeff, T., P. Sophie and M. Nigel, 2005. A summary of passive and Active treatment technologies for acid and metalliferous drainage. Proceedings of the 5th Australian Workshop on Acid Drainage, Aug. 29-31, Fremantle, Western Australia, pp: 1-49.
Johnson, D.B. and K.B. Hallberg, 2005. Acid mine drainage remediation options: A review. Sci. Total Environ., 338: 3-14. DOI: $10.1016 /$ j.scitotenv.2004.09.002

Konig, T.N., S. Shulami and G. Rytwo, 2012. Brine wastewater pretreatment using clay minerals and organ clays as flocculants. Applied Clay Sci., 67: 119-124.

Lyew, D. and J. Sheppard, 2001. Technical note use of conductivity to monitor the treatment of acid mine drainage by sulphate-reducing bacteria. Water Resources, 35: 2081-2086.

Madzin, Z., F.M. Kusina and F. Yusof, 2016. Water quality monitoring for heavy metal contamination associated with acid mine drainage at abandoned and active mining sites in Pahang. Proceedings of the International Conference on Agricultural and Food Engineering (AFE' 16).

Mohd Syahrir, M.Z. and K.P. Seong, 2012. Study of Acid Mine Drainage (AMD) potential at penjom gold mine, Pahang using static and kinetic test method. Proceedings of the 2nd International Conference on Water Resources, n.p.

Nunes, L.J.R., J.C.O. Matias and J.P.S. Catalao, 2016. Biomass combustion systems: A review on the physical and chemical properties of the ashes. J. Renewable Sustainable Energy Rev.

Ochola, C. and H.K. Moo-Young, 2005. Reclaimed Limestone Residuals (RLR) for the treatment of acid mine drainage. Proceedings International Conference on Energy, Environment and Disaster, Jul. 24-30, Charlotte NC.

Rios, C.A., C.D. Williams and C.L. Roberts, 2008. Removal of heavy metals from Acid Mine Drainage (AMD) using coal fly ash, natural clicker and synthetic zeolites. J. Hazardous Mater., 156: 23-35.

Sangita, G.U. and P. Bably, 2010. Studies on environmental impact of acid mine drainage generation and its treatment: An appraisal. IJEP, 30: 953-963.

Simmons, J., P.K. Ziemkiewicz and D.C. Black, 2001. Use of steel slag leach reds for the treatment of acid mine drainage. Proceedings of the National Association of Abandoned Mine Lands Annual Conference, Aug. 19-22, Athens, Ohio.

Smith, R.M., W.E. Grube, T.J. Arkele and A. Sobek, 1974. Mine spoil potentials for soil and water quality. Environ. Protection Agency, West Virginia, US.

Smith, M.W. and K.B.C. Brady, 1990. Evaluation of acid base accounting data using computer spreadsheets. Proceedings of the Mining and Reclamation Conference and Exhibition, Charleston, West Virginia, Apri. 23-26, Morgantown, pp: 213-219. 
Sobek, A.A., W.A. Schuller, J.R. Freeman and R.M. Smith, 1978. Field and laboratory methods applicable to overburdens and minesoils: U.S. Environmental Protection Agency Environmental Protection Technology EPA-600/2-78-054, pp: 203.

Tsukamoto, T.K. and G.C. Miller, 2004. Column experiment for microbiological treatment of acid mine drainage. Water Res., 33: 1365- 1370.

USEPA Method 1311, 1999. TCLP; Test Methods for Evaluating Solid Waste, Physical/Chemical Methods. 3rd Edn., Washington, DC: U.S. Environmental Protection Agency, Office of Solid Waste. U.S. Government Printing Office.

USEPA, 1994. Technical Document of Acid Mine Drainage Prediction. 1st Edn., Office of Solid Waste, Washington, USA, pp: 48.
WHO, 2011. Radiological Aspects: Guidelines for Drinking Water Quality, third ed. World Health Organization, Geneva, pp. 197-209.

Young, S.H., J.Y. Seung, O. Chamteut, C.C. Yong and S.A. Joo, 2017. Geochemical and eco-toxicological characteristics of stream water and its sediments affected by acid mine drainage. Catena.

Ziemkiewicz, P.K. and J.G. Skousen, 1998. The use of steel slag in acid mine drainage treatment and control. Proceedings of the 9th Annual West Virginia Surface Mine Drainage Task Force Symposium, Morgantown, Apri. 7-8, West Virginia. 